\title{
Giant cell tumor of the cervical spine: review and case report
}

\author{
Natally Marques Santiago ${ }^{1}$, Adelmo Ferreira ${ }^{2}$, Gilberto Otta ${ }^{3}$, Adriano Torres Antonucci', \\ Bruno Oliveira Azevedo², Luiz Henrique Garcia Lopes², Pedro Garcia Lopes ${ }^{4}$
}

Department of Neurosurgery, University Hospital of the North of Paraná (HURNP), UEL, Paraná, Brazil

\begin{abstract}
The giant cell tumor of bone is a primary neoplasm, which can be locally aggressive, benign or low grade malignant tumors, that is uncommon in the vertebrae above the sacrum and even more rare in the cervical spine. Tumor radical excision, "en bloc" is considered the ideal treatment, however frequently not doable, mainly in the cervical spine due to critical neurovascular structures involvement. Adjuvant radiotherapy can be used in cases of subtotal resection or tumor relapse, lowering recurrence rates of the tumor. Case report: female patient, 25 years-old, presenting with cervical pain e sensitivity disturbance in her left arm, with diagnosis of bone neoplasm in C3-C5. She underwent subtotal resection of the lesion, confirming the diagnostic of giant cell tumor of bone, cervical spine arthrodesis and adjuvant radiotherapy. On 30-month follow-up, she was out of pain complains with total recovery of the left arm sensibility.
\end{abstract}

\section{KEYWORDS}

Giant cell tumors, spine arthrodesis, radiotherapy.

\section{RESUMO}

Tumor de células gigantes da coluna cervical: revisão e relato de caso

O tumor de células gigantes da coluna é uma neoplasia primária que pode ser localmente agressiva, benigna ou com baixo grau de malignidade, sendo incomum em vértebras acima do sacro e ainda mais raro na coluna cervical. A excisão radical do tumor, "em bloco", é considerada o tratamento ideal, entretanto não é sempre factível, principalmente na coluna cervical pelo envolvimento de estruturas neurovasculares críticas. Radioterapia adjuvante pode ser usada em casos de ressecção subtotal ou recidiva tumoral, com redução da recorrência da neoplasia. Relato de caso: paciente do sexo feminino, de 25 anos, com quadro de cervicalgia e disestesia em membro superior esquerdo, com diagnóstico de processo expansivo afetando os corpos vertebrais de C3-C5. Foi submetida à exérese subtotal da lesão, com diagnóstico de tumor de células gigantes, artrodese de coluna cervical e radioterapia adjuvante. Sem recidivas no seguimento em 30 meses.

\section{PALAVRAS-CHAVE}

Tumores de células gigantes, fusão vertebral, radioterapia.

\section{Introduction}

Giant cell tumor (GCT) of bone are primary bone neoplasms, aggressive or low grade, that are rare in the vertebrae above the sacrum, and even more uncommon in the cervical spine. ${ }^{1-4}$ This tumor is histologically benign, but there is a high recurrence rate. ${ }^{4}$ Nevertheless they may present low potential malignancy and local aggressiveness. Histologically, they are characterized by many multinucleated osteoclast-type cells in a background of oval or plump, spindle-shaped uninucleated cells. Marginal excision should be performed as much as possible while preserving the neural function. ${ }^{5}$ Unlike thoracic and lumbar spine, a strictly "en bloc" resection is rarely possible in the cervical spine because of the need to preserve the vertebral arteries and the nerve root supplying the upper limbs. ${ }^{6}$ Postoperative radiotherapy may be considered in those cases as an option to prevent local recurrence when total resection is not possible.

The authors report a literature review about giant cell tumor of the cervical spine based on data research in Medline, including reports from 1970 to 2008, and also report one case which was treated and followed by the neurosurgery staff of HURNP.

1 Neurosurgery resident at Paraná Regional Universitary Hospital (HURNP), State University of Londrina (UEL), PR, Brazil.

2 Neurosurgeon at HURNP, UEL, PR, Brazil.

3 Radiologist at HURNP, UEL, PR, Brazil.

4 Neurosurgeon, chief of Neurosurgery Department of HURNP, UEL, PR, Brazil. 


\section{Case report}

A 25 -year-old female patient presented with a 2 year-long history of cervical pain and irradiation to the left arm. She developed lowering of her arm sensibility to every sensation. A physical examination revealed a $5 / 5$ strength in all lower extremity muscle groups, with intact sensation. X-ray evidenced large destructive process affecting the vertebral bodies of C3-C5. Magnetic resonance imaging (MRI) of her cervical spine revealed lowering and flattening of the vertebral body of $\mathrm{C} 4$ and involvement of C3 and C5 vertebral bodies (Figure 1) and it also showed the extension of this lesion to the left pedicle and posterior arch, causing the blot out of left conjugation foramen of $\mathrm{C} 4 / \mathrm{C} 5$ (Figure 2).

The patient underwent an open surgery of the lesion and she was treated by anterior resection, then by $\mathrm{C} 3$ to C5 vertebral body removal. The tumor was richly vascularized, soft consistency, violet colored, presenting no cleavage plane related to the contiguous soft tissue. During the same surgical procedure the patient underwent a spine roller fixation with iliac bone graft from C2 to C6. Twelve days after, the patient was subsequently taken to the operating room and underwent a posterior cervical spine fixation with inter spinous titanium wire and iliac bone bars from $\mathrm{C} 2$ to $\mathrm{C} 6$ was also performed. Then a laminectomy at $\mathrm{C} 3$ and $\mathrm{C} 4$ level was accomplished for dural bag decompression. Histological sections of the tumor showed multinucleated giant cells. These histological features were diagnostic of giant-cell bone tumor.

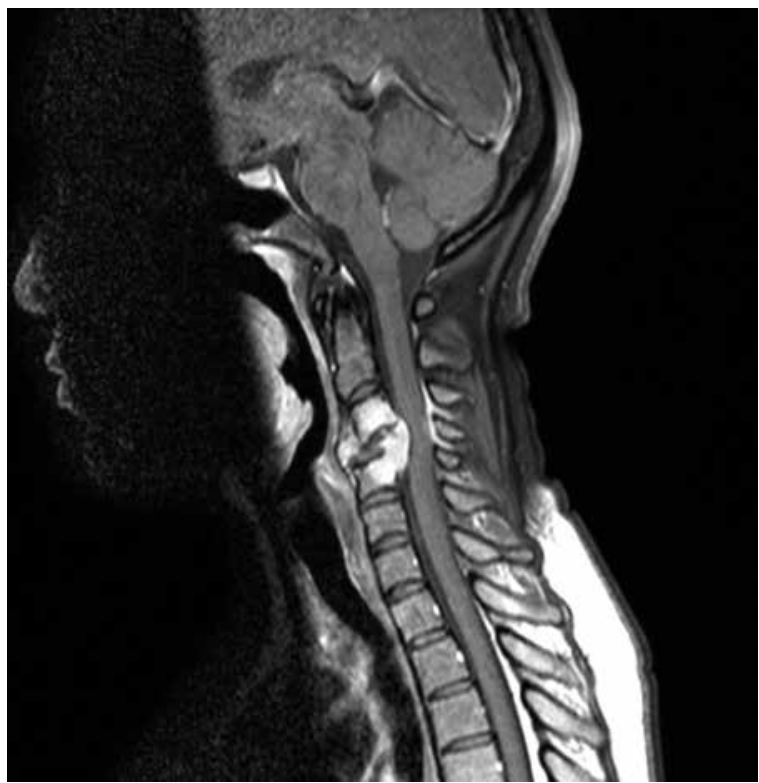

Figure 1 - Magnetic resonance imaging (MRI) sagital contrastenhanced T1-weighted of the cervical spine revealed lowering and flattening of the vertebral body of C4 and involvement of $\mathrm{C} 3$ and C5 vertebral bodies.
She was referred to postoperative radiotherapy (RT) with $4000 \mathrm{cGy}$ in 20 fractions, as adjuvant therapy. On 30-month follow-up, she was out of pain complains with total recovery of the left arm sensibility. Follow-up $\mathrm{X}$-rays showed no instability in spine fixation (Figure 3). Repeated magnetic resonance studies did not reveal growth of the lesion (Figure 4).

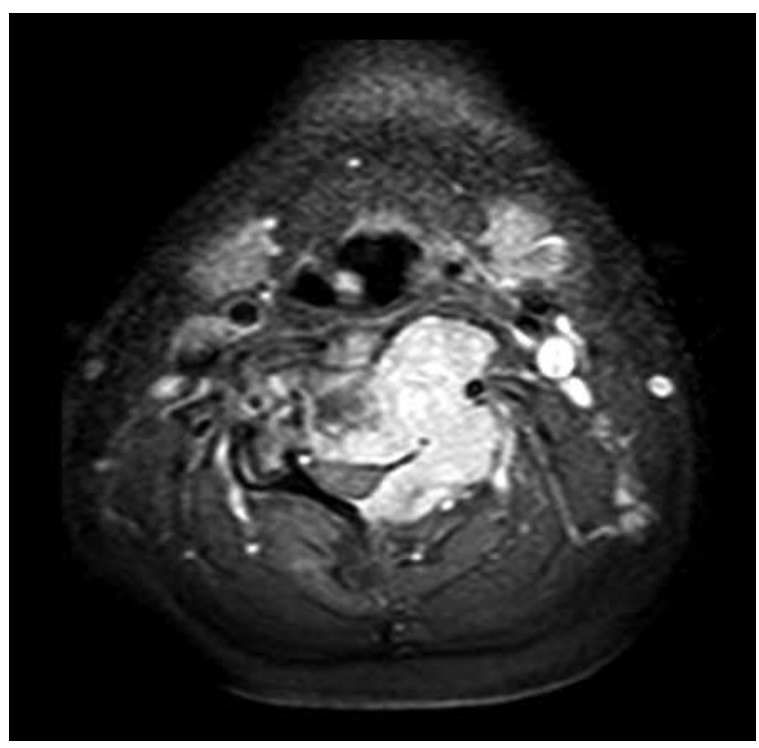

Figure 2 - Magnetic resonance imaging (MRI) axial contrastenhanced T1-weighted showing extension of this lesion to the left pedicle and posterior arch, causing the blot out of left conjugation foramen of $\mathrm{C} 4 / \mathrm{C} 5$.

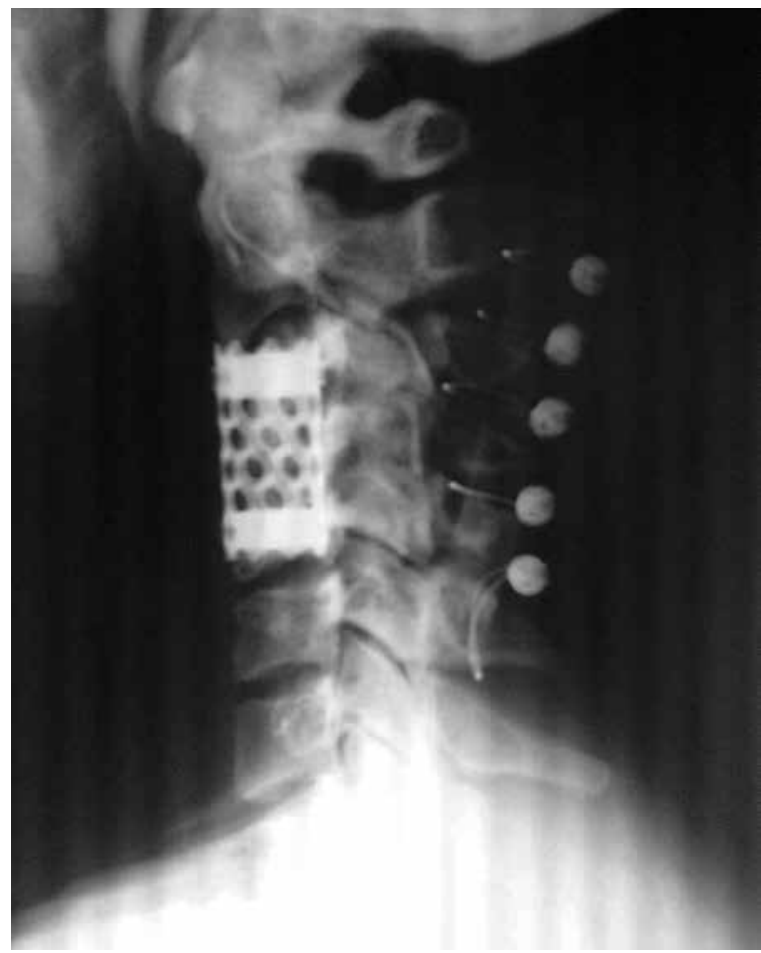

Figure 3 - Post operative lateral X-ray showing spine fixation. 


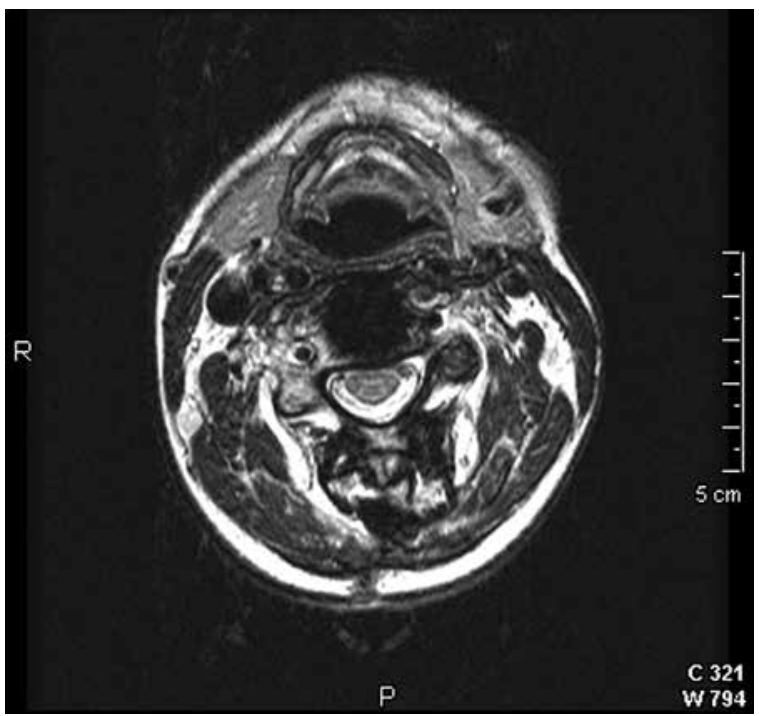

Figure 4 - Magnetic resonance imaging (MRI) axial contrastenhanced T1-weighted (C4) did not showing growth of tumor.

\section{Discussion}

Giant cell tumor of the spine, excluding the sacrum, are rare. ${ }^{1}$ Only 2 to $3 \%$ of giant cell tumors reported affect the spine above the sacrum, and the incidence of these tumors in the cervical spine may be less than $1 \% .{ }^{7,8}$ Sanjay et al. ${ }^{3}$ found that pain was the presenting symptom in all and half of the 24 patients reported had a neurological deficit. Abdelwahab et al. ${ }^{1}$ reported the difficulties in radiological diagnosis of giant cell tumor as they may be confused with metastatic carcinoma, plasmacytoma, lymphoma, chordoma and even benign lesions, particularly aneurysmal bone cyst and brown tumor of hyperparathyroidism. The lesion are histologically similar in appearance even to Paget's disease of bone. ${ }^{5}$ On the other hand, their bubbly appearance and vertebral body rarefaction may be helpful characteristics. An "en bloc" resection of giant cell tumor performing an aggressive treatment is the standard procedure because of the local invasive behavior of this lesion and the unpredictable course. On the other hand, because of the relatively complicated anatomic structure of the cervical spine, the complex bone supply and neural structures, an aggressive resection pose more difficulties to the surgeons, thoroughly excising the tumor is very difficult to be accomplished. ${ }^{1,5}$ In many cases, a combined access (anteriorly and posteriorly) is necessary. ${ }^{3}$ In some cases, spine fixation with many different modalities of devices are necessary. The effectiveness of instrumentation surgery in the reconstruction of the spine after extensive surgery has been reported by in literature. ${ }^{9}$

When total resection is not possible, the local recurrent rate is supposed to be high and local infiltration demand careful management. The overall recurrence rate for the spine tumors is 25 to $45 \%{ }^{3,10}$ In cases of single level disease, surgical treatment alone may be considered with good response. However, in cases that the lesion involves multiple levels and/or vascular elements, such as the case the authors presented above, adjuvant radiotherapy may be necessary. RT should be considered an adjuvant to surgery or as alternative therapy in cases of giant cell tumor of bone (GCTB) that are unresectable or in which excision would result in substantial functional deficits. When RT is used as primary therapy, the rate of local control seems to be satisfactory. ${ }^{11}$ We reported a case of a woman successfully treated by partial surgical excision of the tumor because of anatomic difficulties for "en bloc" excision, who also underwent spine fixation and adjuvant postoperative radiotherapy.

In cases of subtotal excision, there are several reports in literature showing giant cell tumor recurrence., , 10,12-14 $^{-1}$ Complete resection of these tumors offers many difficulties, so an adjuvant postoperative treatment as adjuvant radiotherapy fulfills an important role.

Giant cell tumor are benign neoplasms. ${ }^{5,6,15}$ They have the rare ability to become more aggressive and recur as a sarcomatous growth for osteosarcoma. ${ }^{2}$ Radiation as primary or adjuvant treatment is controversial. ${ }^{11}$ Some authors report good results with the combination of both treatment with no tumor recurrence. Other reports suggest that radiation may induce malignant transformation of the tumor. This fact has been reported in some studies. ${ }^{7,8,16}$ Because of the risk of sarcomatous transformation, radiation therapy should be reserved for patients with incomplete excision or for those with local recurrence. ${ }^{3}$ Radiation may be warranted by the importance of achieving total excision and avoiding recurrence for adequate treatment of cervical spine tumors. In the case reported by the authors, long term follow up shows a successful treatment of giant cell tumor of the cervical spine with subtotal resection combined to adjuvant radiotherapy with no local recurrence or malignant transformation.

\section{References}

1. Abdelwahab IF, Camins MB, Hermann G, Klein MJ, Mosesson RE, Casden AM. Giant cell tumour of the seventh cervical vertebra. Can Assoc Radiol J. 1995;46(6):454-7.

2. Erdogan B, Aydin MV, Sen O, Sener L, Bal N, Yalçin O. Giant cell tumour of the sixth cervical vertebrae with close relationship to the vertebral artery. J Clin Neurosci. 2005;12(1):83-5.

3. Sanjay BK, Sim FH, Unni KK, McLeod RA, Klassen RA. Giant-cell tumours of the spine. J Bone Joint Surg Br. 1993;75(1):148-54. 
4. Weinstein JN, McLain RF. Primary tumors of the spine. Spine (Phila Pa 1976). 1987;12(9):843-51.

5. Campanacci M, Baldini N, Boriani S, Sudanese A. Giant-cell tumor of bone. J Bone Joint Surg Am. 1987;69(1):106-14.

6. Junming $M$, Cheng $Y$, Dong $C$, Jianru $X$, Xinghai $Y$, Quan $\mathrm{H}$, et al. Giant cell tumor of the cervical spine: a series of 22 cases and outcomes. Spine (Phila Pa 1976). 2008;33(3):280-8.

7. Dahlin DC. Giant-cell tumor of vertebrae above the sacrum: a review of 31 cases. Cancer. 1977;39(3):1350-6.

8. Goldenberg RR, Campbell CJ, Bonfiglio M. Giant-cell tumor of bone. An analysis of two hundred and eighteen cases. J Bone Joint Surg Am. 1970;52(4):619-64.

9. Shikata J, Yamamuro T, Mikawa Y, Kotoura Y, lida H. Instrumentation surgery for primary tumors of the spine. Arch Orthop Trauma Surg. 1989;108(3):144-9.

10. Hart RA, Boriani S, Biagini R, Currier B, Weinstein JN. A system for surgical staging and management of spine tumors. A clinical outcome study of giant cell tumors of the spine. Spine (Phila Pa 1976). 1997;22(15):1773-82.

11. Caudell JJ, Ballo MT, Zagars GK, Lewis VO, Weber $\mathrm{KL}$, Lin PP, et al. Radiotherapy in the management of giant cell tumor of bone. Int $\mathrm{J}$ Radiat Oncol Biol Phys. 2003;57(1):158-65.
12. García-Bravo A, Sánchez-Enríquez J, Méndez-Suárez JL, Melián-Suárez A, Miranda-Calderín G. Secondary tetraplegia due to giant-cell tumors of the cervical spine. Neurochirurgie. 2002;48(6):527-32.

13. Gille O, Soderlund C, Berge J, Sacko O, Vital JM. Triple total cervical vertebrectomy for a giant cell tumor: case report. Spine (Phila Pa 1976). 2005;30(10):E272-5.

14. Shikata J, Yamamuro T, Shimizu K, Shimizu K, Kotoura Y. Surgical treatment of giant-cell tumors of the spine. Clin Orthop Relat Res. 1992;(278):29-36.

15. Hunter CL, Pacione D, Hornyak M, Murali R. Giant-cell tumors of the cervical spine: case report. Neurosurgery. 2006;59(5):E1142-3.

16. Feigenberg SJ, Marcus RB Jr, Zlotecki RA, Scarborough MT Berrey BH, Enneking WF. Radiation therapy for giant cell tumors of bone. Clin Orthop Relat Res. 2003;(411):207-16.

\section{Correspondence address}

Natally Marques Santiago Rua Paranaguá, 539, ap. 110, Centro 86020-030 - Londrina, PR, Brazil Phone: (55 43) 3344-2948

Mobile phone: (55 43) 9111-3839

E-mail: natallysantiago@hotmail.com 